\title{
Effect of mild cold on metabolic and insulative adaptation in man
}

Citation for published version (APA):

van Marken Lichtenbelt, W. D., Schrauwen, P., \& Westerterp-Plantenga, M. S. (2001). Effect of mild cold on metabolic and insulative adaptation in man. Journal of Thermal Biology, 26, 449-453.

https://doi.org/10.1016/S0306-4565(01)00059-6

Document status and date:

Published: 01/01/2001

DOI:

10.1016/S0306-4565(01)00059-6

Document Version:

Publisher's PDF, also known as Version of record

Document license:

Taverne

Please check the document version of this publication:

- A submitted manuscript is the version of the article upon submission and before peer-review. There can be important differences between the submitted version and the official published version of record.

People interested in the research are advised to contact the author for the final version of the publication, or visit the DOI to the publisher's website.

- The final author version and the galley proof are versions of the publication after peer review.

- The final published version features the final layout of the paper including the volume, issue and page numbers.

Link to publication

\footnotetext{
General rights rights.

- You may freely distribute the URL identifying the publication in the public portal. please follow below link for the End User Agreement:

www.umlib.nl/taverne-license

Take down policy

If you believe that this document breaches copyright please contact us at:

repository@maastrichtuniversity.nl

providing details and we will investigate your claim.
}

Copyright and moral rights for the publications made accessible in the public portal are retained by the authors and/or other copyright owners and it is a condition of accessing publications that users recognise and abide by the legal requirements associated with these

- Users may download and print one copy of any publication from the public portal for the purpose of private study or research.

- You may not further distribute the material or use it for any profit-making activity or commercial gain

If the publication is distributed under the terms of Article $25 \mathrm{fa}$ of the Dutch Copyright Act, indicated by the "Taverne" license above, 


\title{
Effect of mild cold on metabolic and insulative adaptation in man
}

\author{
W.D. van Marken Lichtenbelt*, P. Schrauwen, M.S. Westerterp-Plantenga \\ Department of Human Biology, Maastricht University, PO Box 616, 6200 MD, Maastricht, Netherlands
}

\begin{abstract}
(1) Short-term effect of mild decrease in environmental temperature $\left(16^{\circ} \mathrm{C}\right.$ versus $\left.22^{\circ} \mathrm{C}\right)$ on $24 \mathrm{~h}$ energy expenditure and body temperature distribution were measured in nine men in a respiration chamber. (2) At $16^{\circ} \mathrm{C}$, body temperature (both skin and core) decreased and temperature gradients within the body increased, together with an increase in energy expenditure. (3) In response to mild cold, the change in body temperature gradients was negatively related to changes in energy expenditure. (4) The results show that inter-individual differences exist with respect to the relative contribution of metabolic and insulative adaptations to mild cold. (C) 2001 Elsevier Science Ltd. All rights reserved.
\end{abstract}

Keywords: Body temperature; Temperature gradient; Energy expenditure; Thermoregulation; Respiration chamber

\section{Introduction}

Studies on the effect of ambient temperature on metabolism in humans often concentrate on either energy expenditure (EE) (Dauncey, 1981; Conzolazio et al., 1963; Valencia et al., 1992), or body temperature (Montgomery and Williams, 1976; Savage and Brengelmann, 1996; Brengelmann et al., 1994). Few studies looked at the interaction of energy metabolism and body temperature (Rising et al., 1992; Rising et al., 1995; Ravussin and Swinburn, 1993; Marken Lichtenbelt et al., 2001). However, people may differ in their physiological adaptations to environmental temperature. This has been shown for different ethnic groups (among others: Scholander et al., 1958; Iampietro et al., 1959). Therefore, looking at both the EE and body temperature distribution within a population may provide insight into individual differences in response to changes in environmental temperature.

Theoretically, three types of thermoregulatory adjustments have been described during long-term adaptation to a colder environment (Jansky, 1997): hypothermic

*Corresponding author. Tel.: +31-43-3881629; fax: +31-433670976.

E-mail address: markenlichtenbelt@hb.unimaas.nl (W.D. van Marken Lichtenbelt). adaptation (lowered thermoregulatory set point), insulative adaptation (subcutaneous fat and/or more efficient vasoconstriction), and metabolic adaptation (or nonshivering thermogenesis). During short-term exposure to mild cold, people may differ in their response to the relative contribution of insulative and metabolic adaptation.

Indeed, exposure to mild cold has been shown to increase the temperature gradient, i.e. a reduction of peripheral temperature at relatively constant core temperature (Hardy and Du Bois, 1938), whereas other studies showed that energy metabolism increased (Blaza and Garrow, 1983; Dauncey, 1981). However, the combination of measuring the components of the EE together with body temperature distribution in response to mild cold has not been studied before.

Therefore, we studied the short-term effect of mild decrease in environmental temperature $\left(16^{\circ} \mathrm{C}\right.$ versus $22^{\circ} \mathrm{C}$ ) on energy metabolism and body temperature distribution.

\section{Materials and methods}

Nine healthy male volunteers participated in the study. Body mass was $76.2 \pm 9.4 \mathrm{~kg}( \pm \mathrm{SD})$, body mass 
index (BMI) amounted to $22.7 \pm 2.1 \mathrm{~kg} / \mathrm{m}^{2}$ (range: 20.2-27.4). One subject had the BMI above $25 \mathrm{~kg} / \mathrm{m}^{2}$, with only $18.8 \%$ body fat (BF). On average, the percentage of the $\mathrm{BF}$ was $17.9 \pm 5.4 \%$ (range: $6.1-$ $24.0 \%$ ), and the age was $23.8 \pm 5.1 \mathrm{yr}$. The Medical Ethics Committee of Maastricht University approved the study.

\subsection{Body composition}

The whole body density was determined by underwater weighing in the morning before breakfast. Body weight was measured with a digital balance with an accuracy of $0.01 \mathrm{~kg}$ (Sauter, type E1200). Lung volume was measured simultaneously with the helium dilution technique using a spirometer (Volugraph 2000, Mijnhardt). The percentage of the $\mathrm{BF}$ was calculated using the equation of Siri (Siri, 1961). Fat free mass (FFM) in $\mathrm{kg}$ was calculated by subtracting fat mass from body mass.

\subsection{Energy expenditure}

The tests took place in a $14 \mathrm{~m}^{3}$ respiration chamber, as described in detail by Schoffelen et al. (1997). The room was ventilated with fresh air. The ventilation rate was measured with a dry gas meter (G4 Schlumberger, the Netherlands) and amounted to $70-801 / \mathrm{min}$. The relative humidity was set at $55 \%$, at both $22^{\circ} \mathrm{C}$ and $16^{\circ} \mathrm{C}$. Physical activity was monitored by means of a radar system based on the Doppler principle (Schoffelen et al., 1997). The sensitivity of the radar system is described elsewhere (Schoffelen et al., 1997; Bouten et al., 1995).

$24 \mathrm{~h}$ EE was determined from the $\mathrm{O}_{2}$ consumption and the $\mathrm{CO}_{2}$ production according to Weir (Weir, 1949). Sleeping metabolic rate (SMR) was calculated as the lowest mean EE over three consecutive hours between 24.00 and $7.00 \mathrm{~h} .24 \mathrm{~h}$ diet induced thermogenesis (DIT) was determined as the meal induced increase in EE above SMR, corrected for activity induced EE (AEE). This was achieved by plotting the EE against radar output. The intercept of the regression line at the offset of the radar, at zero physical activity, represents the EE in the inactive state: resting energy expenditure (RMR), consisting of the SMR plus the DIT. The DIT was calculated by subtracting the SMR from the RMR (Bouten et al., 1996; Randall et al., 1997; Westerterp et al., 1998). The AEE was obtained by subtracting the DIT and the SMR from the $24 \mathrm{~h}$ EE. For one subject, one measurement on $24 \mathrm{~h} \mathrm{EE}$ is missing (day 1 of the $16^{\circ} \mathrm{C}$ stay).

\subsection{Body temperature}

The skin temperature of subjects was measured continuously from 8.00 to $24.00 \mathrm{~h}$ by means of thermistor surface contact probes (YSI Series 400 type: 409B, accuracy: $\pm 0.1^{\circ} \mathrm{C}$ ) fixed on the skin with a thin, air-permeable adhesive surgical tape. The probes were applied to the following standardized regions: forehead $\left(T_{\mathrm{fo}}\right)$, ventral of the liver $\left(T_{\mathrm{li}}\right)$, and on nondominant sides of thigh $\left(T_{\mathrm{th}}\right)$, hand $\left(T_{\mathrm{ha}}\right)$, and foot $\left(T_{\mathrm{fo}}\right)$. Distal skin temperatures were calculated using $T_{\mathrm{ha}}$ and $T_{\mathrm{fo}}$, while proximal skin temperatures were derived by averaging $T_{\mathrm{fo}}, T_{\mathrm{li}}$, and $T_{\mathrm{th}}$. The thermometric probes were calibrated to within $0.05^{\circ} \mathrm{C}$ in a water bath against a reference mercury thermometer (accuracy: $\pm 0.02^{\circ} \mathrm{C}$ ).

The core temperature of the subjects was measured rectally by means of a conventional digital thermometer (Philips HP 5315, accuracy: $0.1^{\circ} \mathrm{C}$ ) that was inserted $3.5-4 \mathrm{~cm}$. From 24.00 to $8.00 \mathrm{~h}$, rectal temperature was measured using thermistor probes (YSI Series 400, accuracy: $\pm 0.1^{\circ} \mathrm{C}$ ). Temperature measurements were thoroughly explained to the subjects before they entered the respiration chambers.

Temperature gradients were calculated as the differences between core and proximal skin temperatures, core and distal skin temperatures, and proximal skin and distal skin temperatures.

\subsection{Protocol}

The study took place at the Department of Human Biology, Maastricht University, during the winter, from November 1998 to March 1999. Part of a larger study is presented here. Subjects stayed one time for $60 \mathrm{~h}$ $(20.00-8.00 \mathrm{~h})$ in the respiration chamber, at $16^{\circ} \mathrm{C}$ and one time for $36 \mathrm{~h}$ at $22^{\circ} \mathrm{C}$, in random order. The first night was for accustomization and the data analyses was carried out two times, for $24 \mathrm{~h}\left(16^{\circ} \mathrm{C}\right)$ and another $24 \mathrm{~h}$ $\left(22^{\circ} \mathrm{C}\right)$ from $8.00-8.00 \mathrm{~h}$. The body weight was determined before and after each stay in the chamber and the subjects weighed themselves each morning before breakfast after voiding. The interval between each stay in the chamber was between 1 and 4 weeks.

We measured two days at $16^{\circ} \mathrm{C}$ to study the effect of acclimation to correct for possible effects of a lowered ambient temperature on the EE. For pairwise comparison of the $22^{\circ} \mathrm{C}$ and $16^{\circ} \mathrm{C}$ stays, day 2 of the $16^{\circ} \mathrm{C}$ stay was used.

The subjects were fed in energy balance, which was based on individually calculated EE. After measuring the SMR, total EE was calculated as SMR $\times 1.65$. Food composition and regimens at $22^{\circ} \mathrm{C}$ and $16^{\circ} \mathrm{C}$ were identical. The macronutrient composition was $49 \%$ / $15 \% / 36 \%$ of energy, for carbohydrate/protein/fat, respectively.

The clothing was identical during all experiments, was tested in advance, and was comfortable at both ambient temperatures. The outfit consisted of one T-shirt, one cotton shirt, one jogging shirt $(70 \%$ cotton and $30 \%$ polyester), one pair of jogging trousers $(50 \%$ cotton and 
Table 1

Mean body temperatures $( \pm \mathrm{SD})$ of rectum and skin (distal and proximal) and body temperature gradients ${ }^{\mathrm{a}}$

\begin{tabular}{|c|c|c|c|c|c|}
\hline & $16^{\circ} \mathrm{C}$ Day 1 & $16^{\circ} \mathrm{C}$ Day 2 & $22^{\circ} \mathrm{C}$ & $p$ values & \\
\hline$T_{\text {rec }}(24 \mathrm{~h})$ & $36.7 \pm 0.4$ & $36.7 \pm 0.4 b$ & $36.8 \pm 0.3 \mathrm{~b}$ & & $0.02 \mathrm{~b}$ \\
\hline$T_{\text {rec }}$ (day) & $36.9 \pm 0.5$ & $36.9 \pm 0.5$ & $37.1 \pm 0.3$ & & \\
\hline$T_{\text {rec }}$ (night) & $36.5 \pm 0.8$ & $36.4 \pm 0.2$ & $36.5 \pm 0.3$ & & \\
\hline$T_{\text {prox }}$ & $32.1 \pm 0.8 \mathrm{a}$ & $32.1 \pm 0.9 \mathrm{~b}$ & $33.3 \pm 1.0 \mathrm{ab}$ & $0.001 \mathrm{a}$ & $0.002 \mathrm{~b}$ \\
\hline$T_{\text {dist }}$ & $27.8 \pm 2.0 \mathrm{a}$ & $27.7 \pm 1.9 b$ & $32.5 \pm 0.8 \mathrm{ab}$ & $0.0001 \mathrm{a}$ & $0.0001 \mathrm{~b}$ \\
\hline$T_{\text {rec-dis }}$ & $9.1 \pm 21.0 \mathrm{a}$ & $9.2 \pm 1.9 \mathrm{~b}$ & $4.6 \pm 0.7 \mathrm{ab}$ & $0.0002 \mathrm{a}$ & $0.0001 \mathrm{~b}$ \\
\hline$T_{\text {rec-prox }}$ & $4.9 \pm 1.0 \mathrm{a}$ & $4.8 \pm 1.0 \mathrm{~b}$ & $3.7 \pm 0.6 \mathrm{ab}$ & $0.003 \mathrm{a}$ & $0.006 \mathrm{~b}$ \\
\hline$T_{\text {prox-dis }}$ & $4.3 \pm 1.8 \mathrm{a}$ & $4.5 \pm 1.6 \mathrm{~b}$ & $0.8 \pm 0.6 \mathrm{ab}$ & $0.0002 \mathrm{a}$ & $0.0001 \mathrm{~b}$ \\
\hline
\end{tabular}

${ }^{\text {a }}$ Pairwise significant differences by paired $T$-test are given by letters 'a' and/or 'b'.

$50 \%$ polyester) and a pair of sport shoes during the day. The total insulative capacity of the clothing amounted to 0.71 Clo. Subjects did not wear socks. At night, subjects were asked to wear a T-shirt and boxer shorts and lay under a cotton sheet and duvet, weighing $375 \mathrm{~g} / \mathrm{m}^{2}$. Daily activities were standardized by describing every hour, and sometimes every $15 \mathrm{~min}$, what the subjects were supposed to do. It included household activities, standardized extensive aerobic exercise, and sedentary activities such as reading and watching television. Meal and snack times were also standardized.

\subsection{Statistics}

Results are expressed as mean values \pm SD. For pairwise comparisons, students $T$-test was used. Pearson correlation coefficients were used to test associations between variables. Partial correlation was used to evaluate the relation between the change in body temperature gradients and the change in EE corrected for the percentage of the BF.

\section{Results}

Comparing the results from day 2 at $16^{\circ} \mathrm{C}$ with that of $22^{\circ} \mathrm{C}$ showed that proximal skin temperatures were $1.2 \pm 0.8^{\circ} \mathrm{C}$ lower at $16^{\circ} \mathrm{C}(p<0.001)$, while distally the difference was $4.8 \pm 1.6^{\circ} \mathrm{C}(p<0.0001$; Table 1$)$. At $16^{\circ} \mathrm{C}$, body core temperature was significantly $0.2 \pm 0.15^{\circ} \mathrm{C}$ lower than at $22^{\circ} \mathrm{C}(p<0.02)$.

Temperature gradients increased significantly at $16^{\circ} \mathrm{C}$ compared to that at $22^{\circ} \mathrm{C}\left(T_{\text {rec-dis }}: p<0.0001, T_{\text {rec-prox }}\right.$ : $p<0.005, T_{\text {prox-dis }}: 0.0001$; Table 1).

Temperature gradients between days 1 and 2 at $16^{\circ} \mathrm{C}$ were significantly related $\left(T_{\mathrm{rec}}-T_{\mathrm{dis}}: R^{2}=0.89\right.$, $p<0.002 ; \quad T_{\text {rec }}-T_{\text {prox }}: R^{2}=0.94, \quad p<0.0001 ; \quad T_{\text {prox }}-$ $T_{\text {dis }}: R^{2}=0.87, p<0.005$; for example, see Fig. 1).

Energy balance $(\mathrm{EB}=\mathrm{EI}-\mathrm{EE})$ was not significantly different from zero during the test days (Table 2). At $16^{\circ} \mathrm{C}, 24 \mathrm{~h}$ EE increased compared to $22^{\circ} \mathrm{C}(p<0.02)$.

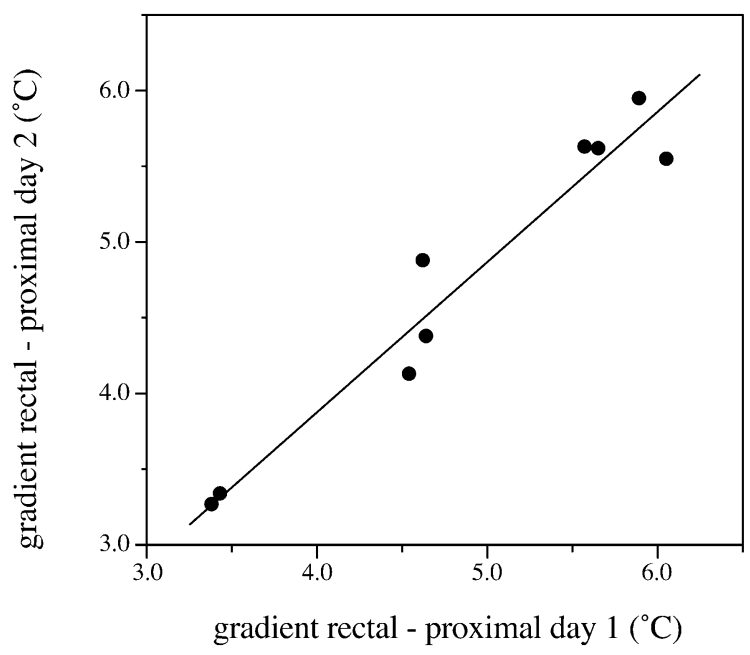

Fig. 1. Relationship between the gradients $\left(T_{\text {rectal }}-T_{\text {proximal }}\right)$ on two consecutive days at $16^{\circ} \mathrm{C}$ during energy balance $\left(R^{2}=0.94, p<0.0001\right)$.

The DIT and the AEE at $16^{\circ} \mathrm{C}$ also increased significantly compared to $22^{\circ} \mathrm{C}(p<0.002$ and $p<0.05)$.

In search of acclimation effects, days 1 and 2 at $16^{\circ} \mathrm{C}$ were compared. $24 \mathrm{~h} \mathrm{EE}$ and AEE were elevated on day $2(p<0.02$, and $p<0.05$, respectively). No significant differences in mean body temperatures were found. However, individual differences were clearly evident: some individuals increased their gradient $\left(T_{\text {rec }}-T_{\text {prox }}\right)$, while others decreased that gradient. $24 \mathrm{~h} \mathrm{EE}$ increased on average, but with large individual differences (mean change in $24 \mathrm{~h} \mathrm{EE:} 0.6 \mathrm{MJ} / \mathrm{d}$ with a range of -1.4 to 0.1 ). The relation between the change in temperature gradients was significantly $(p<0.002)$ negatively related to the change in $24 \mathrm{~h} \mathrm{EE} \mathrm{(Fig.} \mathrm{2).} \mathrm{This} \mathrm{means} \mathrm{that} \mathrm{those}$ subjects with little or no increase in $24 \mathrm{~h}$ EE showed an increase or no change in their body temperature gradient, while those that increased their $24 \mathrm{~h}$ EE showed a decrease in their body temperature gradient. 
Table 2

Mean values of the different components of energy expenditure (EE: energy expenditure, SMR: sleeping metabolic rate, PAI: physical activity index, AEE: activity induced energy expenditure, DIT: diet induced thermogenesis) and energy balance (EB) ${ }^{\mathrm{a}}$

\begin{tabular}{|c|c|c|c|c|c|}
\hline & $16^{\circ} \mathrm{C}$ Day 1 & $16^{\circ} \mathrm{C}$ Day 2 & $22^{\circ} \mathrm{C}$ & $p$ values & \\
\hline $24 \mathrm{~h} \mathrm{EE}$ & $12.05 \pm 1.60 \mathrm{a}$ & $12.91 \pm 2.01 \mathrm{ab}$ & $12.17 \pm 2.23 \mathrm{~b}$ & $0.02 \mathrm{a}$ & $0.02 \mathrm{~b}$ \\
\hline SMR & $7.53 \pm 097$ & $7.67 \pm 1.08$ & $7.44 \pm 1.06$ & & \\
\hline PAI & $1.64 \pm 0.11$ & $1.68 \pm 0.11$ & $1.63 \pm 0.13$ & & \\
\hline AEE & $4.69 \pm 0.94 \mathrm{a}$ & $5.23 \pm 1.13 \mathrm{ab}$ & $4.72 \pm 1.34 b$ & $0.03 \mathrm{a}$ & $0.03 \mathrm{~b}$ \\
\hline DIT & $1.34 \pm 0.51 \mathrm{a}$ & $1.71 \pm 0.41 \mathrm{~b}$ & $0.95 \pm 0.51 \mathrm{ab}$ & $0.03 \mathrm{a}$ & $0.001 \mathrm{~b}$ \\
\hline EB & $0.89 \pm 0.96 \mathrm{a}$ & $-0.22 \pm 0.99 \mathrm{a}$ & $-0.25 \pm 0.85$ & $0.05 \mathrm{a}$ & \\
\hline
\end{tabular}

${ }^{a}$ Significant differences by paired $T$-test are given by letters 'a' and/or 'b'.

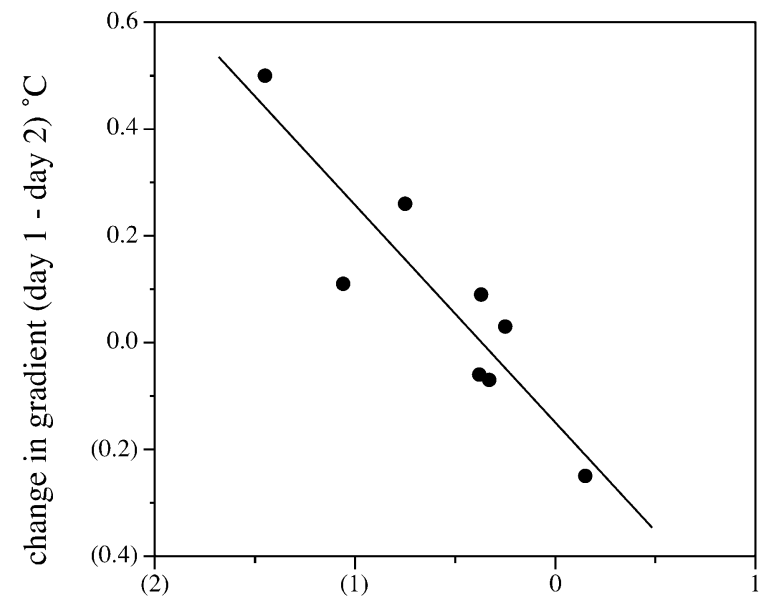

change in $24 \mathrm{~h} \mathrm{EE}$ (day 1 - day 2) $\mathrm{MJ} / \mathrm{d}$

Fig. 2. Changes from days 1 to 2 in body temperature gradient $\left(T_{\text {rectal }}-T_{\text {proximal }}\right)$ plotted against the changes in $24 \mathrm{~h} \mathrm{EE}$ $\left(R^{2}=0.82, p<0.002\right)$. Data from the energy balance experiment at $16^{\circ} \mathrm{C}(16 \mathrm{EBd} 1$ and $16 \mathrm{EBd} 2)$.

Since one subject had a BMI $>25 \mathrm{~kg} / \mathrm{m}^{2}$, the regression analysis was also performed without the data from this subject. The negative relationship was still significant $\left(R^{2}=0.63 ; p=0.03\right)$.

\section{Discussion}

Short-term exposure to $16^{\circ} \mathrm{C}$ of normal-weight men (one exception: BMI of $27.4 \mathrm{~kg} / \mathrm{m}^{2}$ ) who were used to an ambient temperature of $22^{\circ} \mathrm{C}$ (normal temperature in the building and in most rooms in the Netherlands) caused a significant decrease in body temperature (both skin and core), an increase in temperature gradients (insulative adaptation), and an increase in the EE (metabolic adaptation). In response to mild cold, the change in body temperature gradients was negatively related to changes in the EE. This shows that inter-individual differences exist with respect to the relative contribution of metabolic and insulative adaptations to cold.

The slight but significant decrease in core body temperature at $16^{\circ} \mathrm{C}$ relative to $22^{\circ} \mathrm{C}$, combined with much larger decreases in skin temperatures confirms earlier studies: mild cold was shown to increase the temperature gradient, i.e. a reduction of peripheral temperature at relatively constant core temperature (Hardy and Du Bois, 1938).

In response to mild cold, $24 \mathrm{~h}$ EE increased significantly with $0.74 \mathrm{MJ} / \mathrm{d}$, comprising an increase of $6 \%$. This approaches the values reported by Dauncey (1981), who found an increase in $24 \mathrm{~h}$ EE of $7 \%$ over a comparable change in environmental temperature $\left(6^{\circ} \mathrm{C}\right)$. Our results indicate that the increase in $24 \mathrm{~h}$ EE can be attributed to increases in the DIT, the AEE, and nonshivering thermogenesis (Westerterp-Plantenga et al., this volume).

Combining the results of the EE and the body temperatures, we found a significant negative relation between the changes in body temperature gradient ( $\left.T_{\text {rectal }}-T_{\text {proximal }}\right)$ from days 1 to 2 during the $16^{\circ} \mathrm{C}$ test and the change in $24 \mathrm{~h} \mathrm{EE}\left(R^{2}=0.82\right)$. This means that those subjects with hardly any increase in $24 \mathrm{~h}$ EE showed an increase or no change in the temperature gradient, while those with a clear increase in $24 \mathrm{~h} \mathrm{EE}$ showed a decrease in the temperature gradient. The results indicate a continuous relationship between those subjects showing mainly a metabolic adaptation during the two test days combined with a relative large decrease of the insulative component, and those showing hardly any or no metabolic adaptation with a slight increased insulative component. Since the range in percentage of the BF was large, insulation by the BF may have differed between individuals and may explain this trend. There was no simple relation between the changes in body temperature gradient and the percentage of the $\mathrm{BF}$. Besides, partial correlation revealed that the relationship between the change in gradient and $24 \mathrm{~h}$ EE was independent of the percentage of the BF. 
The inter-individual differences in the short-term response to a cold environment implicate individual differences in energy conserving mechanisms that may explain individual differences in predisposition to obesity. Whether these differences are of genetic origin cannot be deduced from this study. It has been shown several decades ago that adaptive changes to cold exposure can be brought about experimentally in man (Brück et al., 1976). This means that the differences in response to mild cold can partly be explained by differences in daily living circumstances. Nevertheless, a genetic component cannot be ruled out and deserves further investigation.

\section{References}

Blaza, S., Garrow, J.S., 1983. Thermogenic response to temprature, exercise and food stimuli in lean and obese women, studied by $24 \mathrm{~h}$ direct calorimetry. Br. J. Nutr. 49, 171-180.

Bouten, C.V.C., Pannemans, D.L.E., Westerterp, K.R., Verduin, M., 1995. Physical activity assessment during standardized activity in a respiration chamber: movement registration versus energy expenditure. Int. J. Obes. Relat. Metab. Disord. 19, 29.

Bouten, C.V., Marken Lichtenbelt, W.D.v., Westerterp, K.R., 1996. Body mass index and daily physical activity in anorexia nervosa. Med. Sci. Sports Exerc. 28, 967-973.

Brengelmann, G.L., Savage, M.V., Avery, D.H., 1994. Reproducibility of core temperature threshold for sweating onset in humans. J. Appl. Physiol. 77, 1671-1677.

Brück, K., Baum, E., Schwennicke, H.P., 1976. Cold-adaptive modifications in man induced by repeated short-term coldexposures and during a 10-day and -night cold exposure. Pflügers Arch. 321, 159-172.

Conzolazio, C.F., Matoush, L.-R.O., Nelson, R.A., Torres, J.B., Isaac, G.J., 1963. Environmental temperature and energy expenditures. J. Appl. Physiol. 18, 65-68.

Dauncey, M.J., 1981. Influence of mild cold on $24 \mathrm{~h}$ energy expenditure, resting metabolism and diet-induced thermogenesis. Br. J. Nutr. 45, 257-267.

Hardy, J.D., Du Bois, E.F., 1938. Basal metabolism, radiation, convection and vaporization at temperatures of 22 to $35^{\circ} \mathrm{C}$. J. Nutr. 15, 477-497.

Iampietro, P.F., Goldman, R.F., Buskirk, E.R., Bass, D.E., 1959. Response of Negro and white males to cold. J. Appl. Physiol. 14, 798-800.
Jansky, L., 1997. Adaptability to cold: from mouse to man. In: Nielsen-Johannsen, B., Nielsen, R. (Eds.), Thermal Physiology 1997. Copenhagen, pp. 163-170.

Marken Lichtenbelt, W.D.v., Westerterp-Plantenga, M.S., Van Hoydonk, P., 2001. Individual variation in the relation between body temperature and energy expenditure in response to elevated ambient temperature. Physiol. \& Behav. 73, in press.

Montgomery, L.D., Williams, B.A., 1976. Effect of ambient temperature on the thermal profile of the human forearm, hand, and fingers. Ann. Biomed. Engin. 4, 209-219.

Randall, D., Burggren, W., French, K., 1997. Eckert Animal Physiology: Mechanisms and Adaptations. W.H. Freeman and Co., New York.

Ravussin, E., Swinburn, B.A., 1993. Metabolic predictors of obesity: cross-sectional versus longitudinal data. Int. J. Obes. Relat. Metab. Disord. 17, S28-31.

Rising, R., Keys, A., Ravussin, E., Bogardus, C., 1992. Concomittant interindividual variation in body temperature and metabolic rate. Am. J. Physiol. 263, E730-734.

Rising, R., Fontvieille, A.M.A., Larson, D.E., Spraul, M., Bogardus, C., Ravussin, E., 1995. Racial difference in body core temperature betweeen Pima Indian and Caucasian men. Int. J. Obes. 19, 1-5.

Savage, M.V., Brengelmann, G.L., 1996. Control of skin blood flow in the neutral zone of human body temperature regulation. J. Appl. Physiol. 80, 1249-1257.

Schoffelen, P.F.M., Westerterp, K.R., Saris, W.H.M., Hoor, F.t., 1997. A dual-respiration chamber system with automated calibration. J. Appl. Physiol. 83, 2064-2072.

Scholander, P.F., Hammel, H.T., Hart, J.S., LeMessurier, D.H., Steen, J., 1958. Cold adaptation in Australian aborigines. J. Appl. Physiol. 13, 211-218.

Siri, W.E., 1961. In: Bozek, J., Henschel, A. (Eds.), Techniques for Measuring Body Composition. National Academy of Sciences, Washington, DC, pp. 223-224.

Valencia, M.E., McNeill, G., Brockway, J.M., Smith, J.S., 1992. The effect of environmental temperature and humidity on $24 \mathrm{~h}$ energy expenditure in men. Br. J. Nutr. 68, 319-327.

Weir, J.B., 1949. New methods for calculating metabolic rate with special reference to protein metabolism. J. Physiol. 109, $1-9$.

Westerterp, K.R., Wilson, S.A.J., Rollnd, V., 1998. Diet induced thermogenesis measured over $24 \mathrm{~h}$ in a respiration chamber: effect of diet composition. Int. J. Obes. Relat. Metab. Disord. 22, 1-6.

Westerterp-Plantenga, M.S., Marken Lichtenbelt, W.D.v., Schrauwen, P., 2001. Core-skin gradient body temperature related to nonshivering thermogenesis in humans at a lowered ambient temperature. Therm. Biol., this volume. 